\title{
ПОВЫШЕНИЕ РЕСУРСА ДЕТАЛЕЙ ПЛУНЖЕРНЫХ ПАР
}

\author{
Представил д-р техн. наук, профессор Э.С. Геворкян
}

\begin{abstract}
Введение. Ремонт прецизионных пар трения является одним из важнейших вопросов, связанных с поддержанием работоспособности деталей транспортного назначения. Высокое оснащение транспортного комплекса высокопроизводительной техникой и механизмами обязывает современное ремонтное производство повышать свой технический уровень технологии ремонта, всемерно совершенствовать организацию производства, расширять технические возможности производства. Повышению срока службы деталей и техники, в целом, наукой и практикой придается огромное значение. Поэтому ремонт является объективной необходимостью поддержания в работоспособном состоянии транспортной техники. Одним из главных условий, обеспечивающих высокий уровень организации ремонта транспортной техники, является качественное и своевременное обеспечение предприятий запасными частями. Расходы на запасные части имеют большой вес в общей стоимости ремонта техники. Однако они могут быть значительно сокращены путем расширения объемов восстановления изношенных деталей с применением прогрессивных технологий.
\end{abstract}

Постановка проблемы в общем виде, связь с научными и практическими заданиями. Подавляющая часть транспортной техники оснащена дизельными двигателями, надежность и экономичность которых в значительной мере предопределяется техническим состоянием деталей топливной аппаратуры и прежде всего ее плунжерных пар.
На практике из-за крайне низкого уровня технического обслуживания и несоблюдения эксплуатационных требований к топливной аппаратуре плунжерные пары часто подвергаются преждевременным износам [1].

Высокая стоимость материала, высокие требования к их изготовлению и характер износа обуславливают необходимость восстановления плунжерных пар, что, несомненно, обеспечит значительную экономию средств и сырья, а также применение современных технологий при их производстве.

Применяемые на ремонтных предприятиях методы восстановления изношенных плунжерных пар не получили широкого распространения из-за целого ряда недостатков и, прежде всего, из-за высокой себестоимости и технологических трудностей.

Поэтому остается актуальной задача разработки нового технологического процесса изготовления и восстановления деталей с использованием комплексного метода нанесения покрытий.

Анализ последних исследований и публикаций. Надежность топливной аппаратуры в значительной мере определяется надежностью прецизионных деталей, к которым относятся плунжерные пары. Учитывая особые условия работы, данные детали изготовляют из высоколегированных или конструкционных сталей, имеющих высокую твердость, износостойкость и коррозионную стойкость и сохраняющих стабильность размеров в процессе эксплуатации. Детали плунжерных пар дизельных двигателей на наших заводах изготовляют из 
шарикоподшипниковой стали ШХ-15, стали ХВГ и хромомолибденовой 25Х5МА [2]. В соответствии с требованиями технических условий твердость цилиндрических рабочих поверхностей плунжерных пар должна быть не ниже HRC 58, параметр шероховатости поверхности втулки и плунжера $\mathrm{R}_{\mathrm{a}}=0,04$ мкм, конусность плунжеров и втулок - не более 0,0006 мм (по длине 20 мм), некруглость не более 0,0005 мм, нецилиндричность 0,0002 мм и диаметральный зазор - не менее 0,0006 мм.

Однако в настоящее время применяется технологический процесс изготовления прецизионных пар, обеспечивающий их селективную сборку без взаимной притирки. В этом случае отклонение от правильной геометрической формы цилиндрических поверхностей плунжерных пар должно быть не более 0,3...0,4 мкм. Высокая стабильность геометрических размеров прецизионных элементов в процессе их эксплуатации достигается специальной термической обработкой.

Восстановление деталей плунжерных пар представляет трудность в связи с их малыми зазорами и высокой точностью изготовления, а также локальностью износа.

Из анализа существующих способов восстановления изношенных деталей покрытиями, к важнейшим факторам, определяющим интенсивность износа сопряженных деталей, относятся способность к образованию химических соединений на поверхностях трения, тепловые свойства, взаимодействие со смазкой, степень химического сродства металла и кислорода. В зависимости от процентного содержания легирующих элементов в сталях они по-разному будут взаимодействовать с кислородом и образовывать оксиды, обладающие различными физико-химическими и антифрикционными свойствами.
Цель статьи. Повышение прочностных характеристик и увеличение pecypca деталей плунжерных пар топливных насосов дизельных двигателей путем разработки технологического процесса восстановления и упрочнения данных деталей с использованием комплексной технологии.

Основной материал. При выборе способа восстановления рабочей поверхности прецизионных пар необходимо исходить из того, что восстановление работоспособности узла должно производиться с наименьшими затратами материальных средств и труда, без нарушения заданной структуры основного металла.

Обеспечение требуемого качества восстановления детали начинается с выбора технологии восстановления, которая оценивается с помощью трех критериев: применимости, долговечности и технико-экономических показателей.

На основе изучения классификации и процесса изнашивания возможна разработка способов восстановления и повышения долговечности прецизионных пар. В настоящее время восстановление плунжерных пар производится следующими методами: перекомплектовки, перекомплектовки с заменой одной из деталей; обработки холодом; диффузионного азотирования и борирования; электроконтактного нанесения (электронатирания); химического никелирования и титанирования; хромирования и оксидирования; нагрева ТВЧ и закалки; обработки с помощью лазера. Однако эти процессы образования композиционных покрытий являются длительными по времени, их осуществление требует применения сложного и дорогостоящего оборудования.

Разработана технология нанесения покрытий, которая обеспечивает антифрикционные свойства прецизионных пар трения. Для этого были проведены стендовые испытания, прогнозирующие 
работоспособность

восстановленных

плунжерных пар .

Для расчета вероятности безотказной работы деталей предлагается следующая зависимость [1]:

$$
\mathrm{P}(\mathrm{T})=0,5 \cdot \varphi\left(\frac{U_{\max }-a_{0}-V_{c p} T}{\sqrt{b_{a}^{2}+T^{2} b_{y}^{2}}}\right),
$$

где $\varphi$ - нормированная функция Лапласа;

$U$ max - предельный износ детали;

$a_{0}$ - начальный параметр детали;

$V_{c p}-$ средняя скорость изнашивания деталей;

$T$ - время наработки;

$b_{a}$ - среднеквадратичное отклонение случайного параметра.

Для деталей плунжерной пары удобнее вместо времени наработки употреблять число $\mathrm{N}$ двойных ходов. Тогда формулу для определения вероятности безотказной работы можно представить как

$$
P(N)=\sum_{s=1}^{n} P_{i}(N)
$$

где $P(N)$ - вероятность безотказной работы одной из деталей в зависимости от наработки, определяемой числом двойных ходов;

$$
n-\text { число элементов }(n=2) \text {. }
$$

В нашем случае $\mathrm{N}=2 \times 10^{6}$ дв. ход, что эквивалентно времени работы $\mathrm{T}=3000$ моточасов.

Принимая для деталей плунжерной пары Umax $=60$ мкм, $\mathrm{a}_{\mathrm{o}}=5$ мкм, $V_{c p}=1,5 \times 10^{-5}$ мкм/ дв. ход, $b_{a}=1$ мкм, по формуле (5.2.), положив в ней $\mathrm{T}=\mathrm{N}=2 \times 10^{6}$ и используются таблицы функции $\varphi$, получим вероятность безотказной работы плунжерной пары [1]:

$$
P_{n \cdot n}=0,5+0,44=0,94 .
$$

Таким образом, в случае длительной работы на надежность влияет в основном износ деталей [3].

Ресурс деталей определяется путем давления величины предельного ее износа на среднюю скорость изнашивания: принимая Umax $=60$ мкм, $V_{c p}=3,08 \times 10^{\prime \prime}$ мкм/дв. ход, получаем $\mathrm{T}=6493$ моточаса.

Отсюда видно, что долговечность плунжерных пар с применением комплексной обработки в 1,3 раза выше обработанных по серийной технологии.

\section{Список литературы}

1. Антипов, В.В. Износ прецизионных деталей и нарушение характеристик топливной аппаратуры дизелей [Текст] / В.В. Антипов. - М.: Машиностроение, 1972. - 172 с.

2. Бахтиаров, Н.И. Производство и эксплуатация прецизионных пар [Текст] / Н.И. Бахтиаров, В.Е. Логинов. - М.: Машиностроение, 1979. - С. 204.

3. Рыбакова, Л.М. Структура и износостойкость металла [Текст] / Л.М. Рыбакова, Л.Л. Куксенова. - М.: Машиностроение, 1972. - С. 204.

Ключевые слова: прецизионные пары трения, работоспособность, износостойкость, плунжерные пары, комплексная обработка.

\section{Аннотации}

Розроблено технологічний процес виготовлення та відновлення деталей засобів транспорту на прикладі плунжерних пар паливної апаратури з використанням комплексної 
технології. Проведено розрахунки ймовірності безвідмовної роботи деталей плунжерних пар 3 визначенням їх довговічності і проведено порівняльні випробування 3 деталями, обробленими за серійною технологією.

Разработан технологический процесс изготовления и восстановления деталей средств транспорта на примере плунжерных пар топливной аппаратуры с использованием комплексной технологии. В работе проведены расчеты вероятности безотказной работы деталей плунжерных пар с определением их долговечности и проведены сравнительные испытания с деталями, обработанными по серийной технологии.

The technological process of production and restoration of transport means' parts on the example of plunger assemblies of fuel equipment with the usage of complex technology has been developed. There are carried out calculations of the failure operation probability of plunger assemblies' parts with the definition of their durability in this article. Comparative trials with parts processed by serial technology were conducted. 